\title{
EVOLUTION INTERPRETATION AND THE EUROPEAN CONSENSUS BEFORE THE EUROPEAN COURT OF HUMAN RIGHTS
}

\author{
INTERPRETAÇÃO DA EVOLUÇÃO E O CONSENSO EUROPEU NO TRIBUNAL EUROPEU DOS \\ DIREITOS HUMANOS
}

Pavel Bureš

\begin{abstract}
The interpretation of the European convention on human rights has been shaped by rich jurisprudence of the European Court of human rights which on several occasions had to resort to so-called evolutive interpretation based on the concept of European consensus. This article focuses on basic elements of the interpretation of the Convention ant its position in the application of conventional rights. It gives first a general historical presentation, then deals with different perspectives playing a role for a better understanding of evolutive interpretation and finishes with a general presentation of European consensus which is a key element for evolutive interpretation.
\end{abstract}

Keywords: European Convention on Human Rights. Evolutive interpretation. European consensus. Judicial restraint. Judicial activism.
Resumo: A interpretação da Convenção Europeia sobre Direitos Humanos foi moldada pela rica jurisprudência do Tribunal Europeu de Direitos Humanos que em várias ocasiões teve que recorrer à chamada interpretação evolutiva baseada no conceito de consenso europeu. Este artigo enfoca os elementos básicos da interpretação da Convenção e sua posição na aplicação dos direitos convencionais. Dá, em primeiro lugar, uma apresentação histórica geral, em seguida, lida com diferentes perspectivas desempenhando um papel para uma melhor compreensão da interpretação evolutiva e termina com uma apresentação geral do consenso europeu, que é um elemento-chave para a interpretação evolutiva.

Palavras-chave: Convenção Europeia dos Direitos Humanos. Interpretação evolutiva. Consenso europeu. Contenção judicial. Ativismo judicial.

Recebido em 18 de fevereiro de 2019 Avaliado em 27 de março de 2019 (AVALIADOR A) Avaliado em 26 de março de 2019 (AVALIADOR B)

Aceito em 13 de junho de 2019

Doctor of Laws for Palacký University Olomouc of the Czech Republic; Professor at Palacký University, Czech Republic; pavel.bures@upol.cz 


\section{Historical foundation of the Convention}

An institutionalized version of the European protection of human rights was conceived in the aftermath of the Second World War as a reaction to all atrocities having resulted from State dictatorship and totalitarianism, in order to face a future potential failure of States with respect to the protection of human dignity. ${ }^{2}$ The text of the Convention has been inspired by the Universal Declaration of Human rights adopted in Paris in 1948. Conventional system of human rights protection is based on the article 1 of the Convention, which reads: "The High Contracting parties shall secure to everyone within their jurisdiction the rights and freedoms defined in Section I of this Convention." This shows, firstly, a clear positioning of both types of "international players" States that bear obligations on one hand and on the other hand individuals which are beneficiaries (recipients or holders) of rights and freedoms listed in the Convention or additional protocols to it. Secondly, it shows (and it is also to be seen in contradictory ruling before the Court) a clear opposition between the parties to the procedure. States - being a respondent party and individuals being always claimant (applicant). From the point of view of the creation of international norms on human rights, it is important to stress that States play the normative role first and then a procedural role of defendant party. ${ }^{3}$

Conventional system of human right protection in Europe, conceived in 1950 has however undergone during the years a huge transformation not only from the point of view of the number of contracting parties ${ }^{4}$ and changes of procedural character, ${ }^{5}$ but in substantial approach as well. New rights and freedoms have been added to the Convention by adopting additional protocols and since 1979 the European Court of Human Rights (hereinafter "the Court" or "the ECtHR") has ruled that the Convention is seen as a "living instrument". 6 This has served for an evolutive approach in the process of interpretation of the Convention. Thus, in the situation of ECHR - evolutive interpretation lies within the concept of the Convention as "a living instrument", to be interpreted in "present-day conditions" where the protection of rights embedded in it must be "practical and effective and not theoretical and illusory". ${ }^{8}$

\footnotetext{
2 It is worth to note that the term (human) dignity appears neither in the text of the Preamble to the Convention, nor in its operative articles. "Inherent dignity of all human dignity" serves to support the abolition of death penalty and one can read it in the Preamble to the additional Protocol n ${ }^{\circ} 13$ to the Convention.

3 In human rights adjudication and especially in discrimination issues, one may have a feeling that a violation is somehow presumed, in these situations where a municipal legal framework does not have clear, argumentized and supported position. Or in other cases where it is enough for the applicant to contend his/her psychological suffering without any specific proof.

4 Starting with 10 founding States and reaching the number 47 at the beginning of the 21 century.

5 The procedural system was based on two judicial bodies first, European commission and European Court of Human rights both with a limited access for individuals. Those bodies were joint in 1998 to form a unique international judicial organ with an open access by individuals.

6 ECtHR judgement in the case Tyrer v. United Kingdom, no. 5856/72, 28 April 1978

7 Tyrer v. UK case, ECtHR judgment in the case Marckx v. Belgium, 13 June 1979, no. 6833/74

8 ECtHR judgment in the case Airey v. Ireland, 9 October 1979, no. 6289/73.
} 


\section{Evolutive interpretation}

The phenomenon of evolutive interpretation can be grasped in a limited way solely as an interpretative method (or technique) within the framework of rules of interpretation of international treaties specified in the Art. 31 and 32 of the Vienna Convention on Law of the Treaties. However, broader approach and larger perspectives could be mentioned in this regard. Those perspectives give a rather solid foundation for a general understanding of the phenomenon of evolutive interpretation. Five main perspectives ${ }^{9}$ are going to be presented. But it means there might be more of them, or different aspects of one can be portrayed separately.

\section{a) Theoretical perspective - judicial activism and judicial self-restraint}

Judicial activism or judicial self-restraint are theoretical approaches to judicial activity of higher courts in general (the theory was firstly employed for the U.S. Supreme Court). Some authors put a relationship between those approaches into a "tension between continuity and creativity" (Cox, 1987). Judicial activism approach was also widely debated with respect to the decision-making activity of the Court, and so for the purposes evolutive interpretation (e.g. Marckx v. Belgium case). Different theoretical analyses and outcomes have been presented since. Mahoney (1990) opined that "as far as the European Convention on Human Rights is concerned, the dilemma of activism versus restraint is more apparent than real." (pp. 57-59). And he concludes: "judicial activism and judicial self-restraint are not diametrically opposed and irreconcilable attitudes to adjudication but are rather essential and complementary components of the process of on-going enforcement of the Convention's fundamental rights through judicial interpretation." (Mahoney, 1990, p. 88). Judge Popović (2009), while speaking about judicial activism points out that those "basic approaches are to some extent parallel", she finally concludes on certain predominance of judicial activism over self-restraint ("A range of various techniques used by the Court, such as evolutive interpretation, innovative interpretation, interpretation contrary to the drafters' intent, and autonomous concepts, prove that judicial activism has prevailed in the Court's jurisprudence.") (Popović, 2009, p. 396). If in general, this conclusion of judge Popović seems to be acceptable and logically justified by previous jurisprudential activity of the Court, it does not establish per se any adjudicatory limit to the socalled activism of the Court. And so, the Court has to face different types of reluctance especially from the side of contracting States. (Cf. 2018 Draft Copenhagen Declaration, where the High Level Conference states in point 14 that:

9 Those five perspective with regard to the phenomenon of evolutive interpretation have been already presented in Bureš (2017). 
[it] affirms the importance of securing the ownership and support of human rights by all people in Europe, underpinned by those rights being protected predominantly at national level by State authorities in accordance with their constitutional traditions and in light of national circumstances. (italics are mine).

The wording of this paragraph was criticized in the Court's Opinion on the draft Copenhagen Declaration and has not been finally adopted by the Conference.

\section{b) Practical perspective - intentionalism and textualism revisited}

Intentionalism and/or textualism is another topic closely related to evolutive interpretation. I may even claim that this is a second side of the same coin to judicial restraint. Textualism or intentionalism in material way correspond to what judicial self-restraint is in theoretical and procedural way. And in the same stance, evolutive interpretation (or purposive interpretation) corresponds to judicial activism. Put it in other words, if on one hand judicial activism or selfrestraint represent a theoretical approach to adjudicatory activity of the Court, intentionalism and textualism, and evolutive interpretation on the other hand are practical manifestations of those theoretical approaches. As for judicial activism, textualism/intentionalism are originally linked with U.S. Supreme Court adjudicatory activity. For the purposes of the Convention, Letsas (2007, p. 60) speaks about originalist theories. He differentiates textualism which "argues that a legal provision must mean what it was taken to mean originally, i.e. at the time of enactment" from intentionalism which claims "that a legal provision must apply to whatever cases the drafters had originally intended it to apply." As Popović's conclusion was the predominance of judicial activism over self-restraint, Letsas's conclusion is a failure of originalist theories and a predominance of object and purpose approach with respect to the interpretation of the ECHR. Recently, the contradiction between textualism and purposive approach has been somehow conciliated by judge Sicilianos in the case Magyar Helsinki Bizottság v. Hungary. ${ }^{10}$ In his separate opinion, referring to the evolutive interpretation he claims that "this interpretative method allows the text of a convention to be continuously adapted to "present-day conditions", without the need for the treaty to be formally amended. The evolutive interpretation is intended to ensure the treaty's permanence. The "living instrument" doctrine is a condition sine qua non for the Convention's survival!" Sicilianos stressed then as well the importance of travaux préparatoires for the interpretation of the Convention, however assigning to them the role of subsidiary means.

$\overline{10 \text { GCh. Judgment, } 8}$ November 2016, Application no. 18030/11. 


\section{c) Political perspective - Issue of sovereignty of Contracting States (doctrine of in dubio mitius)}

Very much related to the judicial activism or progressive interpretation, the issue of sovereignty of Contracting States is at stake here. If the contradiction between judicial activism and judicial restraint was wrapped up as a theoretical adjudicative approach, textualism and purposive interpretation its practical manifestation, sovereignty issues with respect to the evolutive interpretation reflects rather legal-political aspects in international law and relations in the framework of regional human rights protection. Two different approaches are at stake here: a traditional one, meaning that in the situation of doubts international treaty - the Convention - should be interpreted restrictively in order to protect state sovereignty. And a new one claiming that in case of doubts the Convention should be interpreted with regard to larger human rights protection (what supports more judicial activism etc.). The doctrine of in dubio mitius is highly related to classical international law and restrictive theory of interpretation. It was widely developed by the Permanent Court of International Justice in the Lotus jurisprudence. Nowadays, in dubio mitius maxim is seen rather as an interpretative presumption which is far to be applied for international treaties on human rights. In this case, it is the presumption of effectiveness (effet utile) which is used by adjudicatory bodies (Herdeger, 2012). For the sake of reconciliation between sovereignty issues mirrored in culturalsocietal situations of Contracting States and the principle of effectiveness, the Court has created through its jurisprudence the doctrine of margin of appreciation. Macdonald (1993) puts it in these words: to "avoid damaging confrontations between the Court and Contracting States over their respective spheres of authority and enables the Court to balance the sovereignty of Contracting Parties with their obligations under the Convention." (p. 123).

\section{d) Structural perspective - characteristics feature of the ECHR, sui generis character leading to constitutionalism?}

Still the same pattern, but now seen from another perspective, where one may focus his attention to specific characteristic of the European Convention on Human Rights. ECHR is far from being classical international treaty, creating reciprocal rights and obligations to States. Here, the individual is a unique holder of rights opposite to States. Thus, the conventional system creates a special situation where we can speak about the European public order, what the Court expressed in its ruling in Ireland v. UK case: ${ }^{11}$ "Unlike international treaties of the classic kind, the Convention comprises more than mere reciprocal engagements between contracting States. It creates, over and above a network of mutual, bilateral undertakings, objective obligations which, in

$\overline{11}$ Cf. ECtHR judgment in Ireland v. the United Kingdom, 18 January 1978, Application no. 5310/71, \$239. 
the words of the Preamble, benefit from a "collective enforcement".) Again here, we may observe a certain tension between treating the Convention as pure international treaty with for example rules of interpretation, position of states and their autonomy on one hand, and the Convention and its case-law creating a unique constitutionalized order for the region.

\section{e) Consequential perspective - the question of predictability (legal certainty)}

Last topic of reference to evolutive interpretation sorts out a little from previous patterns as it touches more States' perspective applicability. It thus may be grasped as a consequence of aforementioned different perspectives. Tensions portrayed before can have for States as consequence a lower threshold of predictability perception, especially in delicate societal issues or issues where margin of appreciation has been till now used. Arises thus the question whether and how States can themselves be aware of the evolution and when necessary change their national legislation in order not to violate the Conventional rights.

All those topics, five perspectives, relate closely and intervene somehow in the sole phenomenon of evolutive interpretation and its possible limits. The Court assesses the changes in societal issues through the technique of the European consensus. The technique was, especially at the beginning, widely criticized by many authors for the lack of transparency, legal predictability and low level of legal certainty (Dzehtsiarou, 2015, p. 115). ${ }^{12}$ Nowadays, the Court and its research unit provide for a better understanding and offer empirical data on national legislation of the issue at stake (Wildhaber, Hjartarson, \& Donelly, 2013). The European consensus is mostly based on national legislation of Council of Europe member States only. Sometimes the Court refers to other instruments - international treaties, soft law documents etc., what is now and then criticized for being a judicial activism. One can understand the need of the Court to ascertain what the presentday conditions are. What is triggering in this regard is the fact the Court does it especially on the basis of national legislations and does not introduce any other values which might be taken into consideration to support its argumentation. It is fascinating to see the easiness of the process, a quite simple arithmetic counting the Court does to examine whether there is a change in societal perception of the issue at stake or not.

From the Court's perspective, the evolutive interpretation is not based upon subsequent practice, ${ }^{13}$ but rather perceived as changes in societal and/or delicate issues. This fact confirms again the specific feature of the Convention as a human rights treaty. It would be difficult to perceived societal changes in Contracting States as mere subsequent practice to the treaty within the meaning of the Art. 31 \& 3 (b), which stipulates: that shall be taken into account, together with the context -

12 For a developed survey of those critical approaches cf. Dzehtsiarou (2015).

13 For general survey on subsequent practice cf. Nolte (2013). 
any subsequent practice in the application of the treaty which establishes the agreement of the parties regarding its interpretation. This subsequent practice thus should lead to an agreement (Crawford, 2013, p. 30), what is not the case when the Court has to deal "only" with the European consensus. But what is triggering more is a total reliance of the Court to changes in societal issues. To put it in more stringent way, one may ask, whether and to what extent the Court is "bound" by the consensus among Contracting States in any situations of changes of societal issues. Should the Court respect all the "democratic principle" of creation of new evolutive interpretation? I could say YES, at least the Court should respect the democratic procedures and national law-making procedures at national level. Even though they might be guided by political opportunism, ideologies etc.

Yes, the Court should respect it provided for national laws aim to the human rights protection. And this is in my view the stumbling block of the whole story. The Court relies on consensus among member states which subsequently leads to the evolution in interpretation of the human rights norms without assessing whether this "subsequent practice" of states is by itself conforming the human rights protection. The Court takes it as an evolution in societal perception.

\section{European consensus - definition and area of application}

European consensus helped many times the ECtHR to find a way for an evolutive interpretation of ECHR. Thus, technically speaking, the European consensus is a tool (or one of the tools) of interpretation. It would amount to an over-estimation, if one speaks about a comprehensive interpretative technique. The Court when resorting to European consensus bases its argumentation usually on comparative studies of the national legal orders of the member States of the Council of Europe. Sometimes a municipal law comparison is sufficient, sometimes the Court relies also on international instruments (be it of hard law $w^{14}$ or soft law ${ }^{15}$ character), or other municipal laws of third countries.

Although, the technical aspect seems to be clear, ${ }^{16}$ one lacks a clear definition of European Consensus which covers the scope of employment and its jurisprudential and/or interpretative impact. A national judge may see in this technique a specific type of judicial activity leading to re-create "international" norms. Martens (2008, p. 83), when seeking for a clear definition, tries to answer the question, whether European consensus is a legal or sociologic notion. Especially, in earlier judgments of the Court when the term of European consensus has not yet been crystalized, the Court used expressions such as: common approach, increased societal acceptation, common European approach, common denominator or others (see above 2.) - notions which refer more to proper sociological reality, than to legal conception. Meanwhile, the Court has to always analyse

\footnotetext{
14 European Social Charter

15 Council of Europe Committee of Minsters recommendations.

16 Even though, statistical data shows that it is not always the case, that the Court is analysing all municipal laws and in depth.
} 
"legal materiel" (Martens, 2008, p. 83). Nowadays, it is evident that "European consensus" is not one autonomous concept, the Court uses in its case-law. ${ }^{17}$ It is not a term the Court would fill with content through its jurisprudential activity. To the contrary, European consensus is more a shortcut to describe a certain use of argumentation or argumentative elements being based on the comparative method. The proper role of the Court, when examining a rather delicate issue, is to decide whether in a particular case the European consensus exists and thus there has been an evolution in societal-legal perception of the situation (e.g. requirement for irreversible changes of sex for a transgender person ${ }^{18}$ ) and the margin for appreciation has been limited considerably. Or unlike, the European consensus has not been established yet, there is maybe a certain tendency, a trend, and thus there is still a space for national manoeuvring. Kovler (2008) presents a conclusion on that point:

It is clear that consensus in the Convention sense does not mean the unanimity that is needed for treaty amendment. It is more an expression of the common ground required for the collective approach underlying the Convention system and the interaction between the European and domestic systems (p. 20).

One can see, the Court is using the term consensus in a new unusual meaning. Uniformity (agreement in opinion) ${ }^{19}$ has turned to a common tendency or statistical majority. According to Dzehtsiarou (2015), "some commentators have taken up these concerns and have argued that the Court should use the term 'trend' instead of 'consensus', and concludes that the term 'trend' better reflects the reality." (p. 13). By using the term consensus, the Court has created a "new terminological reality", a new semantic phenomenon. It remains to be seen, what is rather unclear, in what situation the Court resorts to the use of European consensus argumentation. In the first cases, it was only at the request of applicants, even of third parties (NGOs) and relied on their fact findings in that matter. Nowadays, the ECtHR makes use of its proper research division which examines municipal law of the Council of Europe members in a particular situation.

The usage of European consensus, as a specific technique of interpretation of the Convention, is not limited to particular article/s of the ECHR. Rather it is open to all legal notions with a different possibility of various interpretations. As already stated, we could see that European consensus is not limited to so-called relative rights (Arts. 8 to 11 of the Convention), where the interference of governmental authorities might be permitted and thus in accordance with the international obligation of contracting States ensuing from the Convention. Even in the very first case where the Court has resorted to the consensual technique of interpretation, it has analysed the absolute right of prohibition of torture, inhuman and degrading treatment. ${ }^{20}$ And so, Art. 3 of the

\footnotetext{
17 The Court jurisprudence has abundantly formulated a different autonomous concept related to the notions in the Convention, e.g. direct or indirect victim, family life, court, remedy.

18 ECtHR judgment in case A.P., Garçon et Nicot v. France, 79885/12, 52471/13 et 52596/13 from 6 Avril 2017.

19 Consensus - an opinion that all members of a group agree with. Oxford Advanced Learner's dictionary. OUP, 2000.

20 Cf. Tyrer case.
} 
Convention has been tackled, in other cases where the Court had recourse to some extent to the European consensus technique of interpretation. ${ }^{21}$ Nevertheless, till now the European consensus has been used by the Court mostly in cases dealing with the interpretation of Arts. 8, 10 and 14 of the Convention. ${ }^{22}$ Consequently, the Court in its rich jurisprudence has used in many different cases either an established European consensus to find out the violation of the Convention, or a not yet established consensus (a mere trend ${ }^{23}$ ) to rule on a non-violation of the Convention. Usually, when it comes to not yet defined European consensus, a mere trend.

From the statistical point of view, Art. 8 (right to private and family life) provides for an extensive implementation of the technique of European consensus. ${ }^{24}$

The main question now remains, whether all these issues can be regarded as societal phenomena and thus be subject to pure societal changes. In different words, in terms of a European consensus or a commonly accepted approach, can we make some difference between the right of prisoners to vote (Hirst), collective bargaining obligations (Sørensen and Rasmussen), full-face veil issues (S.A.S.), surrogacy issue (Manesson and Lebassee), the right to family life for a homosexual couple adopting children ( $X$. and others), right of transgender (Goodwinn) or abortion as one of the reproductive rights (A.B.C.)? We contend that human nature is the same, subject to no changes with regard to societal values. Louis Henkin (2009) puts this idea even for human rights in general terms when he writes: "Human rights are universal: they belong to every human being in every human society. They do not differ with geography or history, culture or ideology, political or economic system, or stage of development." (p. 288). If there is an "evolution" (of human nature), it is the situation where a new aspect of human nature has been unveiled. ${ }^{25}$ Human nature, as unchangeable, is strictly linked to human dignity. To affirm that both, human nature and human dignity can evolve in accordance to societal changes would be to void the term of (human) nature of its meaning. ${ }^{26}$ Human dignity is an element present in the case-law of the Court, ${ }^{27}$ however in its rulings this phenomenon plays hardly the role of a building block of the argumentation. Extra-legal character of the concept of human dignity puts the Court in the area where it does not want to be, to wit the area of philosophical argumentation.

21 E.g. Barar Ahmad and Others v. United Kingdom, Öcalan v. Turkey, Cruz Varas ans Others v. Sweden, Vinter and Others v. United Kingdom.

22 Other articles of the Convention were dealt with to a lesser extent or not at all (Art. 7 or Art. 13).

23 Cf. Wildhaber, Hjartarson, \& Donelly (2013, p. 257).

24 From more than one hundred cases where the European consensus has been used at least $25 \%$ of the time deal with the interpretation of the right to private or family life. More than 10\% relate to Art. 14 (prohibition of discrimination) and less than $10 \%$ to Art. 3 (prohibition of torture). Other substantial articles of the Convention are touched only slightly by the European consensus technique.

25 A typical, non-controversial example is the abolition of the death penalty. European consensus between contracting parties to the additional Protocol no. 6 to the Convention shows that a basic aspect of human nature (life) has to be preserved even in the situation of a state's criminal sanction. Moreover, statistics have shown that the death penalty deterrence has no evidential effect and there might be a lot of miscarriages of justice.

26 We are not able, here, to answer the old question of legal philosophy about the process of creation of these norms on human nature. In different words to answer the question who or what rules on what is human nature.

27 Tyrer case, Pretty case, Bouid case and many others where the Court expressed its view theat human dignity is the very essence of the Convention. 


\section{Conclusion}

There are different method of interpretation which are used by international judicial bodies to interpret international treaties. Evolutive interpretation has been largely implemented in judicial work of the European Court of Human rights. Nevertheless, interpretative method based of the evolution of societal issues and thus, new understanding of terms of the Convention does not exist in a vacuum. The Convention (as a living instrument) "lives" in very concrete and real circumstances which form the whole social-judicial-political reality in Europe. That is why five different perspectives have been presented. Those elements - judicial activism, textualism, issue of sovereignty, sui generis character of the Convention and the question of predictability - have been presented to show that the evolutive interpretation in the reality of human rights treaties has to be understand in broad spectrum. The same goes for the phenomenon of European Consensus, which is a specific interpretative tool used by the Court to support the evolutive interpretation. European consensus has been used in different cases. The Court presented its arguments in order to show the evolution of interpretation of different rights of the Convention. The question still remains whether and how changes in societal issues which reflect human rights adjudication should be taken into account in the process of decision about the violation of human rights based on the European Convention of Human Rights.

\section{References}

Bureš, P. (2017, Summer). Human dignity: An illusory limit for the evolutive interpretation of the ECHR? Amicus Curiae, 110, 20.

Cox, A. (1987). The Supreme Court: Judicial Activism or Self-restraint. Maryland Law Review, $47(1), 118-138$.

Crawford, J. (2013). A Consensualist Interpretation of Article 31(3) of the Vienna Convention on the Law of Treaties. In G. Nolte (Ed.). Treaties and Subsequent Practice. Oxford: Oxford University Press.

Dzehtsiarou, K. (2015). European Consensus and the Legitimacy of the European Court of Human Rights. Cambridge: Cambridge University Press.

Henkin, L. (2009, Winter). The Age of Rights, 1-5 (1990). In A. J. Brauch, The Dangerous search for an elusive consensus: What the Supreme Court should learn from the European Court of Human Rights. Howard Law Journal.

Herdeger, M. (2012). Interpretation in international law. In R. Wolfrum (Ed.), The Max Planck Encyclopedia (Vol VI). Oxford: Oxford University Press. 
Kovler, A. (2008). The role of the consensus in the system of the European Court of Human rights. In European Court of Human Rights. Dialogues between judges. Strasbourg: Council of Europe.

Letsas, G. (2007). A Theory of Interpretation of the European Convention on Human Rights. Oxford: Oxford University Press.

MacDonald, R. St. J. (1993). The Margin of Appreciation. In R. St. J. Macdonald, F. Matscher, H. Petzold (Eds.), The European System for the Protection of Human Rights. Dordrecht: Martinus Nijhoff. at 123 .

Mahoney, P. (1990). Judicial Activism and Judicial Self-restraint in the European Court of Human Rights: Two Sides on the same Coin. HRLJ, 11, 57-59.

Martens, P. (2008). Les désarrois du juge national face aux caprices du consensus européen. In Cour européenne des droits de l'homme. Dialogue entre juges. Strasbourg: Conseil de l'Europe.

Nolte, G. (Ed.). (2013). Treaties and Subsequent Practice. Oxford: Oxford University Press.

Popović, D. (2009). Prevailing of Judicial Activism over Self-Restraint in the Jurisprudence of the European Court of Human Rights. Creighton L. Rev., 42, 361-395.

Wildhaber, L., Hjartarson, A., \& Donelly, S. (2013). No Consensus on Consensus? The Practice of the European Court of Human Rights. HRLJ, 33, 248-259). 
